\title{
Surgery course load in Brazilian medical schools
}

\author{
Carga horária de cirurgia em escolas médicas do Brasil
}

\author{
Athos Paulo Santos Martini' (D) athosmartini@gmail.com \\ Sofia Romay Oliveira' (D) sromay10@gmail.com \\ Suely Grosseman ${ }^{1,2}$ (D) sgrosseman@gmail.com
}

\begin{abstract}
Introduction: Surgery is an important curricular component of undergraduate medical courses. This study was conducted because the surgery course load in Brazilian medical has not been systematically explored at the national level.

Objective: To analyze the surgery course load in Brazilian medical schools.

Method: A cross-sectional, descriptive study was carried out with Brazilian medical schools acknowledged by the Ministry of Education, which had begun their activities prior to December 31, 2017 and, as of September 2018, had their curriculum matrix and/or political-pedagogical project with the surgery course load available on the internet. The variables studied were total medical curriculum course load and surgery course load before and during clerkship, as well as the schools' geographic region and fee status. Data analysis was performed using descriptive statistic Student t-test, analysis of variance, and Mann-Whitney $\mathrm{U}$ and Kruskal-Wallis tests, with the null hypothesis rejected for $\mathrm{p}<.05$.

Results: The study included 205 of the country's 323 existing medical schools, of which 175 had available information on the surgery course load during the clerkship, 157 before the clerkship, and 129 had information on course load before and after the clerkship. The median total surgery course load in hours was $815.0\left(P_{25-75}=677.5-992.0\right.$; minimum $=340.0 \mathrm{~h}$; maximum $\left.=1,665.0\right)$, while the mean surgery course load before clerkship in hours was 268.7 ( $S D=140.3$; minimum $=32.0$; maximum $=780.0$ ), with no difference between geographic regions or fee status. During the clerkship, the median course load was 540.0 hours $\left(P_{25-75}=400.0-712.0\right.$; minimum $=170.0 \mathrm{~h}$; maximum $\left.=1,410.0\right)$, with no difference between geographic regions, but with higher values in medical schools with no tuition fees. Regarding the total curriculum course load, the mean percentage of the surgery course load before clerkship was 3.2\% $(S D=1.7)$, the median percentage during the clerkship was $6.4 \%\left(P_{25-75}=5.0-\right.$ 8.2), the median percentage of the total surgery course load was $6.4 \%\left(P_{25-75}=5.0-8.2 \%\right.$, and the median percentage of surgery course load (both periods) was $9.7 \%\left(\mathrm{P}_{25-75}=8.3-11.8 \%\right)$.

Conclusions: Despite the considerable variation in the surgery course load limits, the median of total surgery and the mean of surgery course load before clerkship were similar across geographic regions and fee statuses. The median surgery course load during clerkship was also similar across regions but higher in tuition-free medical schools. The values found in this study can help schools' administrators to assess and plan the surgery course load in their institutions.
\end{abstract}

Key words: Medical Education; Surgery; Curriculum; Course load.

\section{RESUMO}

Introdução: A cirurgia é um importante componente dos currículos dos cursos de graduação em Medicina. Este estudo foi realizado por não se conhecer a carga horária de cirurgia nas escolas médicas brasileiras.

Objetivo: Analisar a carga horária de cirurgia de escolas médicas brasileiras.

Método: Este estudo foi transversal e descritivo, realizado em escolas médicas brasileiras reconhecidas pelo Ministério da Educação que iniciaram atividades até 31 de dezembro de 2017 e disponibilizavam matriz curricular e/ou projeto político-pedagógico com carga horária de cirurgia na internet até setembro de 2018. As variáveis estudadas foram carga horária total e de cirurgia antes do internato e durante esse período, região geográfica e gratuidade das escolas. Os dados foram analisados por meio de estatística descritiva, teste t de Student, análise de variância e testes U de Mann-Whitney e de Kruskal-Wallis, rejeitando-se a hipótese nula quando $p<0,05$.

Resultados: Foram incluídas 205 das 323 escolas médicas existentes, das quais 175 disponibilizavam carga horária de cirurgia no internato; 157, antes do internato; e 129, disponibilizavam ambas as cargas horárias. A mediana da carga horária total de cirurgia foi de 815,0 horas $\left(\mathrm{P}_{25-75}=677,5\right.$ - 992,0; limites: 340,0 - 1.665,0 horas), e a carga horária média antes do internato foi de 268,7 horas (desvio padrão = 140,3; limites: 32,0 - 780,0), ambas sem diferença estatística por região geográfica ou gratuidade da escola. A mediana da carga horária do internato foi de 540,0 horas $\left(P_{25-75}\right.$ =400,0 - 712,0; limites: 170,0 - 1.410,0), sem diferença estatística por região geográfica, mas maior nas escolas gratuitas. Em relação à carga horária total do currículo do curso, a porcentagem média da carga horária de cirurgia antes do internato foi 3,2\% (desvio padrão = 1,7); a porcentagem mediana da carga horária de cirurgia no internato, $6,4 \%\left(P_{25-75}=5,0-8,2\right)$; e a porcentagem mediana da carga horária de ambos os períodos foi de, $9,7 \%\left(P_{25-75}=8,3-11,8\right)$.

Conclusões: Apesar da variação nos limites extremos da carga horária de cirurgia, a mediana de seu total e sua média antes do internato são semelhantes por região geográfica e gratuidade da escola, e sua mediana no internato é também semelhante por região, mas maior em escolas médicas gratuitas. Os valores encontrados neste estudo podem ajudar os gestores na avaliação e no planejamento da carga horária de cirurgia em suas escolas.

Palavras-chave: Educação Médica; Cirurgia, Currículo; Carga Horária.

1 Universidade Federal de Santa Catarina, Florianópolis, Santa Catarina, Brazil.

2 Faculdade Pequeno Príncipe, Curitiba, Paraná, Brazil.

Editor in Chief: Daniela Chiesa

| Associate Editor: Daniela Chiesa

Received on 19/06/20; Accepted on 27/01/21. | Evaluated by double blind review process. 


\section{INTRODUCTION}

Surgery is one of the major areas of medicine and is a component of the undergraduate medical curricula around the world ${ }^{1}$. In the past, a newly trained doctor was expected to be able to perform surgeries. However, the current expectation is that time spent on learning the details of specialized surgical techniques will be a relatively minor part of the curriculum, with advanced training taking place during a residency in surgery ${ }^{1-4}$.

Several factors have contributed to this change in medical education and other areas of knowledge. In the 1970s, Bohoslavsky pointed out inadequate features in the existing model of university education in most parts of the world. There was a discrepancy between educational organization and the productive structure that generated professionals whose training was not aligned with the country's needs. There was also the segmentation of knowledge into fragments due to an ideological inability to see a more integrated reality in its complexity, which resulted in the formation of specialists in fragments of reality. As a consequence, there was a significant schism between knowing and doing, cognition and action, and university and reality ${ }^{5}$.

In medical education, this fragmentation was exacerbated by the curricular reform proposed by Flexner in $1910^{6}$, which was adopted by a majority of medical schools. In parallel, the acceleration in knowledge production has resulted in a progressive increase in medical curricula course load (CL) and students' overburdening with theoretical concepts ${ }^{7,8}$.

In this context, global movements have been organized to align medical training to students' learning needs and the population's individual and collective healthcare needs. Building strength through the 1970 s and $1980 s^{9}$, these processes led to a series of initiatives, with projects, recommendations, and guidelines to medical courses beginning in the 1990s, such as Tomorrow's Doctors in the UK ${ }^{10,11}$, CanMEDS in Canada ${ }^{12}$, Outcome-Based Education ${ }^{14}$ and the Bologna Process ${ }^{15}$ in Europe, and Core Entrustable Professional Activities for Entering Residency in the USA ${ }^{16}$. The recommendations comprised the inclusion in the mandatory curriculum only of content considered essential, content integration, and pedagogical approaches that bridged theory and practice and provided meaningful learning, focusing on the competencies required for the practice of future medical professionals ${ }^{17,18}$.

In Brazil, a national movement to change medical education resulted in the formation of a commission consisting of various institutions involved in medical education, called the National Interinstitutional Commission for the Evaluation of Medical Education (CINAEM), to evaluate medical schools at the national level ${ }^{19}$. The findings of this evaluation supported the collective dialog on necessary changes in medical education and resulted in the creation of the National Curricular Guidelines (NCG) for undergraduate medical programs in $2001^{20}$, which were reviewed in $2014^{21}$. Among their several recommendations, the NCG state that physicians have an ethical, critical, humanistic, and reflective profile, with competence to act as a general practitioner, attending population's individual and collective healthcare needs $\mathrm{s}^{20,21}$.

Particularly concerning surgery, the NCG do not provide specific content on surgery teaching. However, they list key actions of individual healthcare needs, including raising diagnostic hypotheses based on clinical-epidemiological reasoning, identifying prevalent emergencies, and acting autonomously and competently in this context. In addition, the NCG establish that surgery is an essential clerkship component ${ }^{21}$. Therefore, it is expected that medical students develop clinicalsurgical reasoning during their training, diagnose pathologies that may require surgical intervention, and acquire skills to perform basic surgical procedures required by a general medical practitioner, such as sutures, drainage, and punctures ${ }^{7,8}$.

The surgery $C L$ and content have been the subject of international debates and studies. In the United Kingdom, a consensus among surgeons on the surgery content of undergraduate medical curricula stated that the surgery $\mathrm{CL}$ in their medical schools' curricula was insufficient, and more time was needed to ensure that students who received training would be competent in basic surgical procedures ${ }^{22,23}$. In the US, an additional concern regarding the surgery $C L$ was the reduction in the number of doctors choosing careers in surgery following a $30 \%$ reduction in the mandatory surgery $C L$ in medical school clerkships in the $1990 \mathrm{~s}^{24,25}$.

In Brazil, the NCG do not set out CL limits before the clerkship for surgery or any other area ${ }^{21}$. Although this allows medical schools greater flexibility when planning curricula, there is a risk of including too much or too little content in particular areas due to professors' and administrators' choices. As noted by Lima-Gonçalves, the CLs assigned to each subject are crucially important for the curricular structure; however, they have been used as a bargaining chip in curriculum development to ensure each discipline's representativeness, even though contents are not essential to medical training frequently ${ }^{26}$.

National guidelines drawn up by the Cuban Ministry of Education require that country's medical schools train doctors to perform surgeries of prevalent pathologies in the population. To prepare students with the necessary skills, the guidelines establish a 514-hour CL before clerkship and a 416-hour CL during the clerkship, totaling a $\mathrm{CL}$ of 930.0 hours $^{27}$.

A study with 26 medical schools from 16 European countries found that the minimum $\mathrm{CL}$ dedicated to surgery was 90.0 hours in Brussels (Belgium), and the maximum was 
590.0 hours in Athens (Greece) ${ }^{4}$. Another study with 16 medical schools from six countries in southeastern Europe found a surgery CL before clerkship between 180.0 hours in Osijek (Croatia) and 480.0 hours in Sofia (Bulgaria) ${ }^{28}$.

A study including 153 US medical schools conducted by the Association of American Medical Colleges (AAMC) found that the mean surgery $C L$ was 270.0 hours before the clerkship and 720.0 hours during the clerkship, for a mean total surgery CL of 990.0 hours $^{29}$.

In Brazil, the undergraduate medical course at the Federal University of Santa Catarina (UFSC) changed its curriculum in 2003 to align it with the NCG ${ }^{21,30}$. The curriculum is integrated and divided into modules. Adult surgery is taught throughout the Adult Health Module and pediatric surgery in the Child Health Module. The medical course curriculum has 7,670.0 hours, with a total surgery CL of 968.0 hours, comprising 355.0 hours before the clerkship, which includes 90 hours of surgical techniques and experimental surgery (STES), and 613.0 hours during the clerkship.

The literature gap on the surgery $\mathrm{CL}$ in Brazilian medical schools, important part of undergraduate medical curricula, has led us to the following research question:

- "How has the surgery CL been distributed in Brazilian medical schools?"

To answer this question, this study was conducted with the objective of analyzing the surgery $C L$ in Brazilian medical schools.

\section{METHODS}

\section{Design and Ethical Principles}

This study was cross-sectional and descriptive. The research project was not submitted to the ethics committee because the data used are in the public domain. There are no conflicts of interest.

\section{Population and Sample}

The universe comprised all 323 existing Brazilian medical schools until September 2018, acknowledged by the Ministry of Education (MEC) and listed as of September 2018 on the e-MEC website http://emec.mec.gov.br ${ }^{31}$. The inclusion criteria were having started academic activities before December 31, 2017 according to the e-MEC records, having a curriculum matrix or political-pedagogical project (PPP) available on the internet, and having information on the surgery $\mathrm{CL}$.

\section{Data Collection}

The data were collected between March and September 2018, with the information available on the official website of each institution listed on the e-MEC website $^{31}$. In cases where we did not find the curriculum matrix or PPP on the official school website, we searched for them online with the terms "university name" and "medicine" and ("curricular matrix" or "political-pedagogical project" or "course pedagogical project").

The variables collected were curriculum organization, the school's geographic region, administrative affiliation, curriculum organization, total mandatory $\mathrm{CL}$, and mandatory surgery $C L$ before and during the clerkship. We included the surgery $C L$, the General Surgery discipline, as well as the disciplines listed in the National Commission of Medical Residency (CNRM) matrix of the general surgery medical residency programs and the basic surgery prerequisite program $^{32}$. These subjects comprised digestive tract surgery, plastic surgery, head and neck surgery, oncological surgery, vascular surgery, thoracic surgery, pediatric surgery, cardiac surgery, colorectal surgery, and urology. In addition, we included subjects that were part of STES and outpatient surgery, which were clearly surgery-related subjects.

The CLs were standardized as "clock/hours", corresponding to an actual 60-minute hour. When the school specified that the class duration was different from the clock/hour, that time was calculated for the corresponding time in an actual hour. Before the conversion, some schools had one hour of class corresponding to 60,50 , or 45 actual minutes.

\section{Data Analysis}

The data were entered into a database and analyzed with SPSS Statistics 26.0 Premium software.

Data analysis was performed using descriptive statistics, including absolute and relative frequency for categorical data, central tendency measures, mean, standard deviation (SD), and the $95 \%$ confidence interval $(95 \% \mathrm{Cl})$ for variables with a normal distribution. For variables with non-normal distribution, the median and the $25^{\text {th }}$ and $75^{\text {th }}$ percentiles $\left(\mathrm{P}_{25-75}\right)$ were calculated. The minimum and maximum values were also provided when considered appropriate. The normality of the distribution of continuous variables was assessed using the KolmogorovSmirnov test, with values of $\mathrm{p} \geq .05$ interpreted as normally distributed. The Student t-test $(t)$ and analysis of variance $(F)$ were used to compare the scores of parametric continuous variables between two groups. The Mann-Whitney $U$ (U) test was used to compare the scores of two non-parametric continuous variables, and the chi-square $\left(X^{2}\right)$ in the KruskalWallis test was used for comparisons between more than two groups. Statistical test results (STR) are given with the degrees of freedom (df) in brackets.

The null hypothesis was rejected for $p<.05$. 


\section{RESULTS}

Out of 323 existing Brazilian medical schools, 205 had some surgery $\mathrm{CL}$ available on the internet (63.5\%). Among these schools, 175 provided information on the clerkship $\mathrm{CL}$ (85.4\%), 157 on the surgery CL before clerkship (76.6\%), and 129 provided information on both periods (39.8\%).

Among the 157 schools that specified their surgery $\mathrm{CL}$ before clerkship, the curriculum organization was traditional in 81 (51.6\%), problem-based learning in 11 (7.0\%), modular in eight $(5.1 \%)$, with mixed approaches in three $(1.9 \%)$, integrated in one (.6\%), and serial in one (.6\%). The curriculum organization was not specified in 52 schools (33.1\%). This variable was not used in subsequent analyses due to the preponderance of traditional and unspecified approaches.

The STES CL had a non-normal distribution $(p=.000$ in the Kolmogorov-Smirnov test) with a median of 90.0 hours $\left(P_{25-75}=60.0-120.0 \mathrm{~h}\right)$, a mean of 96.2 hours ( $S D=45.2 ; 95 \% \mathrm{Cl}$ $=87.2-105.2$ ), and a range between 30.0 and 300.0 hours.

Table 1 shows the number of Brazilian medical schools with data on surgery $\mathrm{CL}$ by geographic region, administrative affiliation, and fee status.

Table 2 shows the surgery CLs and the total curriculum CL.

Table 3 shows the percentages of surgery CLs concerning the total curriculum CL.

Table 4 shows surgery CLs at the 129 medical schools with these data available on the internet, divided by
Table 1. Distribution of Brazilian medical schools with surgery course load available on the internet by geographic region, administrative affiliation, and fee status.

\begin{tabular}{cccc}
\hline & $\begin{array}{c}\text { Schools } \\
\text { with surgery } \\
\text { CL before } \\
\text { clerkship }\end{array}$ & $\begin{array}{c}\text { Schools } \\
\text { with surgery } \\
\text { CL during } \\
\text { clerkship }\end{array}$ & $\begin{array}{c}\text { Schools } \\
\text { with surgery } \\
\text { CL in both } \\
\text { periods }\end{array}$ \\
Characteristics & $\mathbf{n}(\%)$ & $\mathrm{n}(\%)^{\mathrm{a}}$ & $\mathrm{n}(\%)$ \\
\hline
\end{tabular}

$\begin{array}{cccc}\text { Region } & & & \\ \text { North } & 16(10.2) & 20(11.4) & 13(10.1) \\ \text { Northeast } & 28(17.8) & 42(24.0) & 22(17.0) \\ \text { Center-west } & 10(6.4) & 14(8.0) & 9(7.0) \\ \text { Southeast } & 72(45.9) & 72(41.1) & 59(45.7) \\ \text { South } & 31(19.7) & 27(15.4) & 26(20.2)\end{array}$

Administrative Affiliation

\begin{tabular}{cccc} 
Federal & $48(30.6)$ & $68(38.9)$ & $43(33.3)$ \\
State & $16(10.2)$ & $21(12.0)$ & $13(10.1)$ \\
Municipal & $5(3.2)$ & $6(3.4)$ & $4(3.1)$ \\
Private & $88(56.0)$ & $80(45.7)$ & $69(53.5)$ \\
\hline
\end{tabular}

Tuition status

\begin{tabular}{cccc} 
Yes & $64(40.8)$ & $89(50.9)$ & $56(43.4)$ \\
No & $93(59.2)$ & $86(49.1)$ & $73(56.6)$ \\
\hline Total & $157(100)$ & $175(100)$ & $129(100)$ \\
\hline
\end{tabular}

Abbreviations - CL: course load; $\mathrm{n}(\%)$ : number (absolute frequency) and percentage (relative frequency).

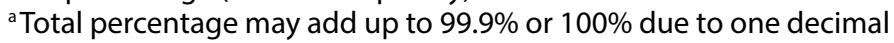
rounding.

Table 2. Total curriculum and surgery course loads in Brazilian medical schools that made the data available on the internet as of September 2018.

\begin{tabular}{|c|c|c|c|c|}
\hline Loads $^{\mathrm{a}}$ & Mean hours (SD) & $95 \% \mathrm{Cl}$ & Median hours $\left(P_{25-75}\right)$ & Min-Max hours \\
\hline CL before clerkship $(n=157)$ & $268.7(140.3)$ & $246.6-290.8$ & $270.0(151.0-360.0)$ & $32.0-780.0$ \\
\hline CL during clerkship $\left(n=175^{b}\right.$ & $582.5(243.0)$ & $546.2-618.7$ & $540.0(400.0-712.0)$ & $170.0-1,410.0$ \\
\hline Total surgery $C L(n=129)^{b}$ & $855.1(266.9)$ & $808.6-901.6$ & $815.0(677.5-992.0)$ & $340.0-1,665.0$ \\
\hline $\begin{array}{l}\text { Total curriculum CL of schools with } \\
\text { any surgery course load available on } \\
\text { the internet }(n=205)\end{array}$ & $8,409.0(937.5)$ & $8,279.9-8,538.1$ & $8,295.0(7,675.0-8,897.0)$ & $6,836.0-13,630.0$ \\
\hline $\begin{array}{l}\text { Total curriculum CL of schools with } \\
\text { surgery course load before clerkship } \\
\text { available online }(n=157)\end{array}$ & $8,420.1(946.2)$ & $8,271.0-8,569.3$ & $8,328.0(7,727.5-8,904.0)$ & $6,984.0-13,630.0$ \\
\hline $\begin{array}{l}\text { Total curriculum CL of schools with } \\
\text { surgery course load during clerkship } \\
\text { available on the internet }(n=175)\end{array}$ & $8,455.9(947.1)$ & $8,314.6-8,597.2$ & $8,375.0(7,720.0-8905.0)$ & $6,836.0-13,630.0$ \\
\hline $\begin{array}{l}\text { Total curriculum } C L \text { of schools with } \\
\text { surgery course load before and } \\
\text { during clerkship available on the } \\
\text { internet }(n=129)\end{array}$ & $8,495.3(954.9)$ & $8,329.0-8,661.7$ & $8,520.0(7,807.0-8,912.0)$ & $7,104.0-13,630.0$ \\
\hline
\end{tabular}

Abbreviations - CL: course load; SD: standard deviation; $95 \% \mathrm{Cl}$ : $95 \%$ confidence interval; $\mathrm{P}_{25-75}: 25$ th and 75 th percentiles; Min-Max: Minimum and Maximum values.

a Course load is equivalent to 60 minutes, and both the mean and median values are given to allow comparisons with other studies.

${ }^{\mathrm{b}}$ Non-normal distribution ( $\mathrm{p}<.05$ in the Kolmogorov-Smirnov test), so the median and 25th and 75th percentiles are given. 
Table 3. Percentage values of partial and total surgery course loads concerning the total curriculum course load in medical schools that made this information available on the internet as of September 2018.

\begin{tabular}{|c|c|c|c|c|}
\hline Percentage values & Mean hours (SD) & $95 \% \mathrm{Cl}$ & Median hours $\left(P_{25-75}\right)$ & Min-Max hours \\
\hline $\begin{array}{l}\text { Surgery CL before clerkship concerning total } \\
\text { curriculum CL in schools with surgery course } \\
\text { load before clerkship available on the internet } \\
(n=157)\end{array}$ & $3.2(1.7)$ & $2.9-3.5$ & $3.3(1.8-4.4)$ & $.35-8.7$ \\
\hline $\begin{array}{l}\text { Surgery CL during clerkship concerning total } \\
\text { curriculum } C L \text { in schools with surgery course } \\
\text { load during clerkship available on the internet } \\
(n=175)^{\mathrm{a}}\end{array}$ & $6.9(2.7)$ & $6.5-7.3$ & $6.4(5.0-8.2)$ & $1.8-15.1$ \\
\hline $\begin{array}{l}\text { \% Total surgery } C L \text { concerning total } \\
\text { curriculum } C L \text { in schools with surgery } C L \\
\text { before and during clerkship available on the } \\
\text { internet }(n=129)^{\mathrm{a}}\end{array}$ & $10.1(3.0)$ & $9.6-10.6$ & $9.7(8.3-11.8)$ & $3.5-18.9$ \\
\hline
\end{tabular}

Abbreviations - CL: course load; SD: standard deviation; 95\%Cl: 95\% confidence interval; $\mathrm{P}_{25-75}: 25$ and 75 percentiles; Min-Max: Minimum and Maximum limits.

${ }^{a}$ Non-normal distribution ( $p<.05$ in the Kolmogorov-Smirnov test), meaning that the median and $\mathrm{P}_{25-75}$ should be considered.

Table 4. Surgery course loads among the 129 medical schools included in the study with data available on the internet by geographic region and school fee status.

\begin{tabular}{|c|c|c|c|c|c|c|}
\hline Characteristics & $\begin{array}{c}\text { Surgery CL } \\
\text { before clerkship } \\
\text { Mean hours (SD) }\end{array}$ & $\begin{array}{c}\text { STR } \\
\text { Test (df); } \\
\text { p }\end{array}$ & $\begin{array}{l}\text { Surgery CL during } \\
\text { clerkship } \\
\text { Median hours }\left(P_{25-75}\right)\end{array}$ & $\begin{array}{c}\text { STR } \\
\text { Test (df); } \\
\text { p }\end{array}$ & $\begin{array}{c}\text { Total surgery } C L \\
\text { Median hours }\left(P_{25-75}\right)\end{array}$ & $\begin{array}{c}\text { STR } \\
\text { Test (df); } \\
\text { p }\end{array}$ \\
\hline \multicolumn{7}{|l|}{ Region } \\
\hline North $(n=13)$ & $275.7(100.2)$ & \multirow{5}{*}{$\begin{array}{l}F(4)=.4 \\
p=.78\end{array}$} & $440.0(395.0-742.0)$ & \multirow{5}{*}{$\begin{array}{c}X^{2}(4)=1.4 \\
p=.85\end{array}$} & $784.0(640.0-1,010.0)$ & \multirow{5}{*}{$\begin{array}{c}X^{2}(4)=1.4 \\
p=.85\end{array}$} \\
\hline Northeast $(n=22)$ & $235.3(107.2)$ & & $583.5(385.0-714.2)$ & & $812.5(651.2-945.5)$ & \\
\hline Center-west ( $n=9)$ & $270.6(164.2)$ & & $560.0(492.0-612.5)$ & & $799.0(682.0-983.5)$ & \\
\hline Southeast $(n=59)$ & $270.3(153.2)$ & & $570.0(420.0-768.0)$ & & $852.0(705.0-1,080.0)$ & \\
\hline South $(n=26)$ & $286.6(131.9)$ & & $505.0(429.5-664.0)$ & & $813.0(675.0-1,008.7)$ & \\
\hline \multicolumn{7}{|l|}{ Tuition-free } \\
\hline Yes $(n=56)$ & $249.8(126.2)$ & \multirow{2}{*}{$\begin{array}{c}t(126)=-1.5 \\
p=.14\end{array}$} & $585.0(427.2-843.0)$ & \multirow{2}{*}{$\begin{array}{c}U=1,609.0 \\
p=.04\end{array}$} & $865.0(706.5-1,125.2)$ & \multirow{2}{*}{$\begin{array}{c}U=1,752.5 \\
p=.17\end{array}$} \\
\hline No $(n=73)$ & $285.2(140.8)$ & & $510.0(400.0-647.0)$ & & $800.0(658.0-915.0)$ & \\
\hline
\end{tabular}

Abbreviations - CL: course load; SD: standard deviation; statistical test results: STR; degrees of freedom: df; $p: p$-value; $P_{25-75}: 25$ and 75 percentiles; $\mathrm{F}$ : factor variance in ANOVA; $\mathrm{t}$ : Student t-test value; $\mathrm{X}^{2}$ : Chi-square value in Kruskal-Wallis test; U: Mann-Whitney test value.

geographical region and fee structure. There was no statistical difference in the $\mathrm{CL}$ between geographic regions. There was no difference between schools with and without tuition in total or before clerkship surgery $\mathrm{CL}$. The only significant difference was a higher median surgery $\mathrm{CL}$ during the clerkship in the tuitionfree schools.

\section{DISCUSSION}

In this study, we found that the minimum and maximum values of surgery $\mathrm{CL}$ before and during clerkship vary across the Brazilian schools studied. However, the mean surgery $\mathrm{CL}$ before clerkship and the median total surgery $\mathrm{CL}$ were similar across geographical regions and schools' fee statuses. The only significant difference we found was the higher median surgery $\mathrm{CL}$ during the clerkship in tuition-free schools.
The wide range of surgery $\mathrm{CL}$ values between schools led us to reflect on the possibility that some schools may offer very low practical and theoretical exposure to surgeryrelated content, which may result in insufficient training to attain the required skills in the area. On the other hand, other schools may include excessive content that is not essential for undergraduate medical training, which may represent an additional burden for students.

It is difficult for us to find a plausible explanation for the higher median $\mathrm{CL}$ during clerkships in tuition-free schools since the definition of this $\mathrm{CL}$ may be influenced by several factors. As there was no significant difference in the median total surgery $\mathrm{CL}$ across schools with different fee statuses, one possible reason may be the way in which the theoretical and practical content is distributed in these schools. However, more consistent 
explanations could only be given after investigating many other aspects beyond the CL. Some of them, for instance, would be the school's view on the value of surgery (which could be assessed by examining the PPP or interviewing administrators), the time at which outpatient practices and surgical procedures begin, the practical settings, and how students are allocated in them, and the number and expertise in surgery of professors/ physicians who participate as preceptors in clerkships.

Regarding the $C L$ values, we were unable to find Brazilian studies that would allow comparison with our findings. Brazilian documentation does exist on the curriculum matrix content for revalidation of diplomas obtained abroad ${ }^{33}$, but without $\mathrm{CL}$ recommendations. In fact, this gap in the literature motivated us to carry out this research and establish a baseline for future comparisons, contributing to the process of developing and evaluating medical curricula.

Some comparisons, though, can be made with the international literature ${ }^{4,27-29}$. In Cuba, the surgery $C L$ before clerkship recommended by the Cuban Ministry of Education is higher than the mean and $95 \% \mathrm{Cl}$ found in our study, and the clerkship and median total surgery CLs are within the percentile ranges found in our sample ${ }^{27}$. These findings make us reflect on the possibility of excessive surgery content in Brazilian medical schools since Cuban doctors are trained to perform a wider range of surgical procedures, which are only performed by surgeons in Brazil.

In the study with 16 medical schools in southeast Europe, five institutions had a mean surgery CL before clerkship lower than the $95 \% \mathrm{Cl}$ of our study, while nine were higher and two within the confidence interval: one of them in Mostar (Bosnia and Herzegovina), and the other in Pristina (Kosovo) ${ }^{28}$.

In the European study with 26 schools, seven had a mean surgery CL before clerkship that was lower than the $95 \%$ $\mathrm{Cl}$ of our study, while 13 were higher and six were within our confidence interval. The latter group was comprised of Split (Croatia), Brno (Czechia), Vienna (Austria), and Rome, Florence, and Naples (Italy) ${ }^{4}$.

The mean surgery $C L$ before clerkship in a survey with 153 US medical schools was within the $95 \% \mathrm{Cl}$ of our study, while the median surgery $C L$ during clerkship was above the $P_{25-75}$ ranges in our study and the median total surgery $C L$ was within the $P_{25-75}$ ranges in our study ${ }^{29}$.

Therefore, we notice that the surgery CLs also vary considerably in European countries and that the $\mathrm{P}_{25-75}$ ranges of Brazilian schools' total surgery $C L$ are consistent with values found in Cuban and American schools. The mean surgery $\mathrm{CL}$ before clerkship and the median surgery $C L$ during clerkship in our study are within the levels found in Cuban schools and lower than American ones.
The limitations of our study included the impossibility of finding the surgery $\mathrm{CL}$ in schools with integrated curricula that did not specify the surgery $\mathrm{CL}$, as well as the impossibility of finding complete documentation in the CLs of all surgery disciplines. Despite the aim of achieving an integrated curriculum in several knowledge areas, the $C L$ dedicated to specific content should ideally be specified in the interest of providing objective parameters for comparison. Another limitation of our study was that we collected data available on the internet, although these data should ideally be collected directly from the medical schools to better understand the theoretical and practical $\mathrm{CL}$ distribution and the content covered.

Finally, we suggest further studies to evaluate the predominant school of thought guiding the schools' curricula, the administrators and professors' perception on what elements of surgery are essential and need to be taught during undergraduate medical courses, and the pedagogical approaches in surgery, including student assessment, practical scenarios, and content.

Our study on $\mathrm{CL}$ of Brazilian medical schools identifies the value/weight that the schools assessed attribute to surgery in their curricula and provides medical school administrators with information on the surgery $C L$ distribution. However, these findings should be considered as the "tip of the iceberg" and are not sufficient to analyze the quality of these medical courses and the factors that influence the decisions regarding surgery $\mathrm{CL}$ at each school ${ }^{34,35}$.

\section{CONCLUSIONS}

Regarding the objectives of our study, although we found considerable variation in the range of surgery $\mathrm{CL}$, there were no significant differences in the mean surgery $C L$ before clerkship, nor in the median total surgery $\mathrm{CL}$ across schools' geographic regions or fee statuses, or the median surgery $C L$ during clerkship across geographic regions. However, the median surgery $C L$ was significantly higher in tuition-free schools.

Our results can help those responsible for medical education to understand the surgery $C L$ distribution in Brazilian medical schools and help medical school administrators to assess and plan the surgery $C L$ accordingly in their institutions.

We suggest further studies including more information, from the political-pedagogical course conception to the surgery instruction scenarios, as well as assessment methods for teaching and students, with data collection including both the schools' existing documents and interviews or focus groups with individuals involved in the teaching and learning process.

\section{AUTHORS' CONTRIBUTION}

Athos Paulo Santos Martini participated in the project 
design, data collection and analysis, and drafting of the manuscript, which was the term paper that he presented as the undergraduate medical course requirement at UFSC. Sofia Romay Oliveira participated in the project design, data collection and analysis, and drafting and review of the manuscript. Suely Grosseman participated as Mr. Martini's advisor and in the project creation, data collection and analysis, drafting, and review of the manuscript.

\section{CONFLICTS OF INTEREST}

The authors declare no conflicts of interest.

\section{SOURCES OF FUNDING}

The authors declare no external sources of funding for this research.

\section{REFERENCES}

1. Agha RA, Papanikitas A, Baum M, Benjamin IS. The teaching of surgery in the undergraduate curriculum-reforms and results. Int J Surg. 2005;3(1):87-92.

2. Agha RA, Papanikitas A, Baum M, Benjamin IS. Part II-importance and recommendations for change. Int. J Surg. 2005, 3(2), 151-157.

3. Baum M. Teaching the humanities to medical students. Clin Med. 2002;2(3):246-249.

4. Dušek T, Bates T. Analysis of European medical schools' teaching programs. Croat Med J. 2003;44:26-31.

5. Bohoslavsky R. Lo vocacional: teoría, técnica e ideología. Buenos Aires: Ediciones Búsqueda; 1975.

6. Flexner A. Medical education in the United States and Canada: a report to the Carnegie Foundation for the advancement of teaching. Bulletin number four. New York: The Carnegie Foundation for the Advancement of Teaching; 1910 [access in 20 aug 2020]. Available from: http://archive. carnegiefoundation.org/publications/pdfs/elibrary/Carnegie_Flexner_ Report.pdf.

7. DiCarlo SE. Too much content, not enough thinking, and too little FUN! Adv Physiol Educ. 2009;33(4):257-64.

8. Andersen S, Stentoft D, Emmersen J, Rasmussen S, Birkelund S, Nøhr S. (2019). Contention over undergraduate medical curriculum content. Int J Med Educ. 2019;10: 230-231.

9. Jonas HS, Etzel SI, Barzansky B. Undergraduate medical education. JAMA. 1990;264(7):801-9.

10. General Medical Council. Tomorrow's doctors: recommendations on undergraduate medical education. London: GMC; 1993 [access in 20 aug 2020]. Available from: https://www.yumpu.com/es/document/ $\mathrm{read} / 47554869 /$ tomorrows-doctors-1993-general-medical-council.

11. General Medical Council. Tomorrow's doctors: outcomes and standards for undergraduate medical education. London: GMC; 2009 [access in 18 jun 2020]. Available from: http:// www.ub.edu/medicina unitateducaciomedica/documentos/TomorrowsDoctors_2009.pdf.

12. Frank JR, Danoff D. The CanMEDS initiative: implementing an outcomesbased framework of physician competencies. Med Teach. 2007;29(7):642-7.

13. Frank JR, Snell L, Sherbino J. Draft CanMEDS 2015: physician competency framework - Series IV. Ottawa: The Royal College of Physicians and Surgeons of Canada; 2015 [access in 18 jun 2020]. Available from: http:// www.royalcollege.ca/portal/page/portal/rc/common/documents/ canmeds/framework/canmeds2015_framework_series_IV_e.pdf.

14. Harden RM. AMEE Guide no 14: outcome-based education: Part 1-An introduction to outcome-based education. Med Teac. 1999;21(1):7-14.
15. World Federation for Medical Education in Europe, University of Copenhagen, Association for Medical Education in Europe. Statement on the Bologna Process and Medical Education. 2005 [access in 18 jun 2020]. Available from: http://www.aic.lv/bolona/Bologna/contrib/Statem_oth/ WFME-AMEE.pdf.

16. Obeso V, Brown D, Aiyer M. Core entrustable professional activities for entering residency: toolkits for the 13 core EPAs. Washington, DC Association of American Medical Colleges; 2017 [access in 10 set 2020]. Available from: https://www.aamc.org/what-we-do/mission-areas/ medical-education/cbme/core-epas/publications.

17. Gomes AP, Rego S. Transformação da educação médica: é possível formar um novo médico a partir de mudanças no método de ensinoaprendizagem? Rev Bras Educ Med. 2011;35(4):557-66.

18. Bollela VR, Machado JLM. O currículo por competências e sua relação com as diretrizes curriculares nacionais para a graduação em medicina. Science in Health. 2010;1(2):126-42.

19. Comissão Interinstitucional Nacional de Avaliação do Ensino Médico. Preparando a transformação da educação médica brasileira: projeto CINAEM III fase relatório 1999-2000. Piccini RX, Facchini LA, Carvalho dos Santos R, organizadores..Pelotas: UFPel; 2000.

20. Brasil. Resolução CNE/CES no 4, de 7 de novembro de 2001. Institui Diretrizes Curriculares Nacionais do Curso de Graduação em Medicina. Diário Oficial da União, Brasília; 9 nov 2001. Seção 1, p. 38.

21. Brasil. Resolução CNE/CES n 3, de 20 de junho de 2014. Institui Diretrizes Curriculares Nacionais do Curso de Graduação em Medicina e dá outras providências. Diário Oficial da União, Brasília; 23 jun 2014. Seção 1, p. 8-11.

22. Baker D, Deekonda P, Glasbey J, Humm G, Mohan H, Nally D, et al. ASiT Medical Student and Foundation Doctor Consensus Group. Core content of the medical school surgical curriculum: consensus report from the Association of Surgeons in Training (ASIT). Int J Surg. 2020, 84:186-193.

23. Hakim MA, Dominguez ED, Priest S, Lee KS, Mardanpour A, Tandle S, et al. Surgical skills workshops should be a part of the United Kingdom undergraduate medical curriculum. Cureus. 2019;11(5): e4642.

24. Polk HC Jr. The declining interest in surgical careers, the primary care mirage, and concerns about contemporary undergraduate surgical education. Am J Surg. 1999;178(3):177-9.

25. Peel JK, Schlachta CM, Alkhamesi NA. A systematic review of the factors affecting choice of surgery as a career. Can J Surg. 2018;61(1):58-67.

26. Lima-Gonçalves L. Médicos e ensino da medicina no Brasil. São Paulo: Edusp; 2002.

27. Miralles AEÁ, Taureaux DN, Fernández SJA, Pernas GM, Sierra FS, Diego CJM. Cronología de los mapas curriculares en la carrera de Medicina. Rev Cuba Educ Méd Super. 2015;29(1):93-107.

28. Likic R, Dusek T, Horvat D. Analysis and prospects for curricular reform of medical schools in Southeast Europe. Med Educ. 2005;39(8):833-40.

29. Association of American Medical Colleges. Curriculum Reports. AAMC Curriculum Inventory, 2018-2019. Washington, DC: AAMC; 2020 [access in 17 aug 2020]. Available from: https://www.aamc.org/data-reports/ curriculum-reports/report/curriculum-reports.

30. Pereima MJL, Coelho EBS, Da Ros MA. Da proposta à ação: currículo integrado do curso de medicina da UFSC. Florianópolis: Editora da UFSC; 2005.

31. Ministério da Educação. Cadastro Nacional de Cursos e Instituições de Educação Superior: cadastro e-MEC. Brasília; 2018 [access in 18 jun 2020] Available from: http://emec.mec.gov.br/.

32. Brasil. Resolução $n^{\circ} 48$, de 28 de junho de 2018. Dispõe sobre a Matriz de Competências dos Programas de Residência Médica em Cirurgia Geral e do Programa de Pré-requisito em Área Cirúrgica Básica no Brasil. Brasília: Comissão Nacional de Residência Médica, Secretaria de Educação Superior; 2018.

33. Brasil. Matriz de correspondência curricular para fins de revalidação de diplomas de médico obtidos no exterior. Brasília: Ministério da Educação, Ministério da Saúde; 2009 [access in 18 jun 2020]. Available from: http:// download.inep.gov.br/educacao_superior/revalida/matriz/2009/matriz_ correspondencia_curricular_revalida_sem_logo.pdf. 
34. Del Ciampo LA, Del Ciampo IRL. Curso de medicina e ensino de pediatria nas escolas médicas brasileiras. Pediatria (São Paulo). 2010;32:9-14.

35. Cutolo LRA, Delizoicov D. O currículo do curso de graduação em medicina da UFSC: análise a partir das categorias Fleckianas. II Encontro Nacional de Pesquisa em Educação em Ciências; 1999; Valinhos. Valinhos: Associação Brasileira de Pesquisa em Educação; 1999. 14 p. [aceso em 18 jun 2020]. Available from: http://abrapecnet.org.br/atas_enpec/iienpec/Dados/ trabalhos/G31.pdf. 